\title{
HEALTH SECTOR CORRUPTION AS THE ARCHENEMY OF UNIVERSAL HEALTH CARE IN INDONESIA
}

\author{
Ratna Juwita* \\ International Law and Internasional Human Rights Law Departement, \\ Faculty of Law Universitas Atma Jaya Yogyakarta \\ Jalan Mrican Baru No.28 Caturtunggal, Sleman, Yogyakarta 55281
}

\begin{abstract}
This article argues that health sector corruption is a direct threat towards universal health care in Indonesia. Three Indonesian legal cases of health sector corruption are selected to exemplify the reality of health sector corruption and its detrimental effect to the realization of the right to health. This article emphasizes that corruption hampers the ability of the State to optimally provide universal health care.This article suggests that in order to establish quality universal health care as an instrument for the realization of the right to health, the state has to prioritize on the elimination of health sector corruption.
\end{abstract}

Keywords: corruption, Indonesia, right to health, health care.

\section{Intisari}

Artikel ini membahas perihal korupsi di sektor kesehatan yang merupakan ancaman bagi perlindungan kesehatan universal di Indonesia. Tiga kasus hukum mengenai korupsi di sektor kesehatan dipilih untuk memberikan gambaran mengenai korupsi di sektor kesehatan dan dampak negatifnya terhadap realisasi hak atas kesehatan. Artikel ini menekankan bahwa korupsi menyebabkan misalokasi dan penggelapan dana yang menghambat Negara dalam penyediaan pelayanan kesehatan yang optimal bagi semua orang. Artikel ini menyarankan bahwa dalam rangka untuk menyelenggarakan perlindungan kesehatan universal yang berkualitas dan berkelanjutan sebagai instrumen untuk merealisasikan hak atas kesehatan, Negara harus memprioritaskan pemberantasan korupsi di sektor kesehatan.

Kata Kunci: korupsi, Indonesia, hak atas kesehatan, perlindungan kesehatan.

\section{Pokok Muatan}

A. Background 163

B. Discussion

1. State Human Rights Obligation to the Right to Health: Universal Health Care as the Realization of the Right to Health in Indonesia

2. International, Regional and National Legal Frameworks on Anti-corruption 166

3. Health Sector Corruption as the Archenemy of Universal Health Care in Indonesia 168

C. Conclusion 172 


\section{A. Background}

Universal health care is a pivotal instrument for the realization of the right to health. Indonesia has made a milestone in ensuring the right to health towards all citizens through Jaminan Kesehatan Nasional (JKN) program. ${ }^{1}$ The program was introduced in 1 January 2014 and aims to cover the whole citizen by $2019 .{ }^{2}$ However, due to health sector corruption, this program might not be able to reach its own designated goal. ${ }^{3}$ Corruption in Indonesia is chronic, malignant and pervasive, it infiltrates almost every sector of the governance. ${ }^{4}$ Health sector is one of the most vulnerable sectors to be corrupted because of its lucrative nature due to the great amount of fund that is allocated within it and the new single authority of Badan Penyelenggara Jaminan Sosial (BPJS) or National Social Security Agency to manage the fund. ${ }^{5}$ The State party of human rights obligation concerning tripartite human rights obligations with regard to the right to health is the establishment of universal health care as a means of realization of the right to health. Health sector corruption is the archenemy of universal health care due to the lost of state fund that it caused. The lost of State fund causes myriad detrimental impacts to the enjoyment of the right to health, inter alia, threat to the availability, accessibility, acceptance and quality health goods, services and facilities. The lost of state fund is an impairment of the ability of the State party to comply with it's human rights obligations. The research problem in this article is whether corruption in health care sector amounts to a violation of human rights. Health sector corruption is exemplified in the analysis of several national case laws. The existence of universal health care is severely jeopardized due to health sector corruption. Conclusively, in order to build quality and sustainable universal health care, the State party has to prioritize on the elimination of health sector corruption because corruption hampers the realization of human rights.

\section{B. Discussion \\ 1. State Human Rights Obligation to the Right to Health: Universal Health Care as the Realization of the Right to Health in Indonesia}

All human being possess human rights as the virtue of being human. ${ }^{6}$ Human dignity is the foundation of all human rights. ${ }^{7}$ The right to the highest attainable standard of health is one of the rights that is declared by the Universal Declaration of Human Rights (UDHR) in 1948 and legally guaranteed by the International Covenant on

See Article 19 of the Law Number 40 Year 2004 concerning the National Social Security System. See also Ian Haydock, “Asian Beat:Political Breathrough Edges Indonesia Closer to Universal Health Care", http://www.pharma-share.com/asia-beat-political-breakthrough-edgesindonesia-closer-universal-care, accessed 1 January 2016. See also Jakarta Post, "Govt Provide Universal Health Coverage", http://www. thejakartapost.com/news/2012/10/13/govt-provide-universal-health-coverage-all.html, accessed 1 January 2016. Based on the Law on National Security System number 40 of 2004, social insurance is defined as "A form of social protection to ensure that all citizens can fulfill their basic needs." The concept of national security system is conducted by several social security agencies. The Government of Indonesia obliged all citizens to contribute in the social insurance in order to establish a pool of funds for the national security system Ibid.

World Bank, 2003, Combating Corruption in Indonesia, Enhancing Accountability for Development, Report, East Asia Poverty Reduction And Management Unit, p. 31; Simon Butt, "Indonesia's Anti-Corruption Drive and the Constitutional Court", Journal of Comparative Law, Vol. 4, Issue 2, 2010, pp. 186-204; Jared Levinson, “Indonesian's Odyssey: A Nation's Long, Perilous Journey to the Rule of Law and Democracy", Arizona Journal of International and Comparative Law, Vol. 18, Issue 1, 2001, pp. 103-129.

4 Transparency International, "Corruption Perception Index 2015”, www.transparency.org, accessed 1 January 2016; James Cassing, "Indonesia in Transition: Will Economic Prosperity Accompany Democracy", Brown Journal of World Affairs, Vol. IX, Issue I, Spring 2002, pp. 95-105; Dwight King, “Corruption in Indonesia: A Curable Cancer?”, Journal of International Affairs, Vol. 53, Issue 2, 2002, pp. 603-624; Leslie Gielow Jacobs and Benjamin B. Wagner, "Limits to the Independent Anti-Corruption Commission Model of Corruption Reform: Lessons from Indonesia", Global Business and Development Law Journal, Vol. 20, 2007, pp. 327-332.

See Article 1 Number 6 of the Law Number 40 Year 2004 concerning the National Social Security System (State Gazette of The Republic of Indonesia Year 2004 Number 150, Supplement to State Gazette of The Republic of Indonesia Number 4456).

The Universal Declaration of Human Rights as the first universally accepted list of human rights assured that every human has human rights. United Nations General Assembly, Universal Declaration of Human Rights, UN GA Resolution 217 (III), $3^{\text {rd }}$ Session, Supp. No. 13, UN Doc $\mathrm{A} / 810,1948,71$.

Donna J. Perry, et al., "The Right to Life in Peace: An Essential Condition for Realizing the Right to Health", Health and Human Rights Journal, Vol. 17, Issue 1, 2015, pp. 149-158. 
Economic, Social and Cultural Rights (ICESCR) in $1966 .{ }^{8}$ The right to health is also recognized by Article 5 (e) (i) of the International Convention on the Elimination of All Forms of Discrimination in 1965, Articles 11.1 (f) and 12 of the Convention on the Elimination of All Forms of Discrimination Against Women in 1979, Article 24 of the Convention on the Rights of the Child in 1989, Articles 28, 43 (e) and 45 (c) of the International Convention on the Protection of the Rights of All Migrant Workers and Members of Their Families in 1990 and Article 25 of the Convention on the Rights of Persons with Disabilities in 2006. ${ }^{9}$ World Health Organization (WHO) defined the goal of universal health care is the assurance that all people obtain the health services that they need, inter alia, prevention, promotion, treatment, rehabilitation and palliation, without the risk of financial ruin or impoverishment, whether it is now and in the future. ${ }^{10}$

In the General Comment, the right to the highest attainable standard of health encompasses a number of freedoms and entitlements that are relevant to a person's health. ${ }^{11}$ The right to health is a right to the enjoyment of health goods, facilities and services, also the conditions necessary for the realization of the highest attainable standard of health. ${ }^{12}$ All rights derived from the life itself, every right stemmed from the life of a human being ever since the moment of conception. The existence of an individual lies in the life itself. As exemplified in this logical narrative that in order to enjoy the right to education to a maximum extent, an individual has to be healthy first. The enjoyment of a human right entangles with the other rights because human rights are interdependent, indivisible and interrelated..$^{13}$

A human rights-based approach empowers people to demand their entitlements from the Government. ${ }^{14}$ Human rights-based approach emphasizes the responsibility of the State Party to provide to the maximum extent possible the enjoyment of human rights to the citizens as the right holders. ${ }^{15}$ States that have ratified international

The Universal Declaration of Human Rights declared that every human being has the right to health in Article 25, "Everyone has the right to a standard of living adequate for the health and well-being of himself and of his family, including food, clothing, housing and medical care and necessary social services, and the right to security in the event of unemployment, sickness, disability, widowhood, old age or other lack of livelihood in circumstances beyond his control".

The ICESCR guaranteed that every individual has the right to health in Article 12, "Everyone has the right to the enjoyment of the highest attainable standard of physical and mental health". Indonesia transformed the ICESCR into its national law through the means of ratification by the Law Number 11 of 2005 concerning the Ratification of the International Covenant on Economic, Social and Cultural Rights (State Gazette of The Republic of Indonesia Year 2005 Number 118, Supplement to State Gazette of The Republic of Indonesia Number 4557). See also Elizabeth Tobin Tyler, "'Small Places Close to Home": Toward A Health and Human Rights Strategy for the U. S.", Health and Human Rights Journal, Vol. 15, Issue 2, 2013, pp. 80-96.

9 Regional human rights recognition over the right to health is chrystalized in Article 11 of the European Social Charter in 1961 , Article 16 of the African Charter on Human and People's Rights in 1981 and Article 10 of the Additional Protocol to the American Convention on Human Rights in the Area of Economic, Social and Cultural Rights in 1988. The right to health is also reiterated in Alma-Ata Declaration in 1978, Vienna Declaration and Programme of Action in 1993 and other international instruments.

10 World Health Organization, 2013, Research for Universal Health Coverage, The World Health Report 2013, World Health Organization, Geneva, p. 4. See also Kathryn O’Neill, "Monitoring Service Delivery for Universal Health Coverage: the Service Availibility and Readiness Assessment", Bull World Health Organ, Vol. 91, 2013, pp. 923-931.; Taryn Vian, et al., "Barriers to Universal Health Coverage in Republic Moldova: A Policy Analysis of Formal and Informal Out of Pocket Payments”, BMC Health Services Research, Vol. 15, 2015, pp. 1-15.

11 General Comment is the interpretive instrument formulated by human rights treaty bodies. The General Comment is used to clarify the human rights conventions in order to make it more applicable and clear in terms. The Committee on Economic, Social and Cultural Rights (Comm ESCR), General Comment number 14 concerning the Right to the Highest Attainable Standard of Health, Article 12, adopted at the Twenty-second Session of the Committee, 11 August 2000, paras. 1 and 8. See also Brigit Toebes, "The Right to Health and the Privatization of National Health Systems: A Case Study of the Netherlands", Health and Human Rights Journal, Vol. 9, Issue 1, 2006, pp. $102-127$.

12 The Committee on Economic, Social and Cultural Rights (Comm ESCR) General Comment Comment number 14, paragraph 9.

13 Paula Braveman, "Social Conditions, Health Equity and Human Rights", Health and Human Rights Journal, Vol. 12, Issue 2, 2010, pp. 31-48.; Alicia Ely Yamin, "Shades of Dignity: Exploring the Demands of Equality in Applying Human Rights Frameworks to Health", Health and Human Rights Journal, Vol. 11, Issue 2, 2009, pp. 1-18.

14 Curtin Francis Doebbler, "The Right to Health of Children and the World Bank", Health and Human Rights Journal, Vol. 5, Issue 2, 2001, pp. 120-146; Sussanah Mayhew, et al., "Balancing Protection and Pragmatism: A Framework for NGO Accountability in Rights-Based Approaches", Health and Human Rights Journal, Vol. 2, Issue 2, 2006, pp. 180-206; Angela Duger, "Focusing on Prevention: The Social and Economic Rights of Children Vulnerable to Sex Trafficking”, Health and Human Rights Law Journal, Vol. 17, Issue 1, 2015 , pp. 114-123.

15 C. Raj Kumar, "Human Rights Approaches to Corruption Control Mechanisms-Enhancing the Hong Kong Experience of Corruption Prevention Strategies", San Diego International Law Journal, Vol. 5, 2004, pp. 323-352; International Council on Human Rights Policy, “The Impacts of Acts of Corruption on the Enjoyment of the Right to Health", Review Meeting, The International Council on Human Rights Policy, Geneva, p. 3. 
human rights treaties are bound with the human rights obligations. ${ }^{16}$ Tripartite human rights obligations oblige the State party to respect, protect and fulfill human rights of the citizens. ${ }^{17}$ The State party also has the positive and negative obligations with regard to human rights. ${ }^{18}$ Positive obligation obliges the State party to take steps to progressively realize the rights that are protected under the ICESCR, negative obligation is in a contrario, it obliges the State party to absent from infringement directly or indirectly with the enjoyment of the human rights. ${ }^{19}$ Negative obligation is attributed to the State party concerning the realization of civil and political rights while positive obligation is attributed to the State party concerning the realization of economic, social and cultural rights. ${ }^{20}$

There are also the concept of obligation of conduct and obligation of result. With regard to economic, social and cultural rights, the obligation of conduct and result is formulated to empirically assess the measures taken by the State Party to realize economic, social and cultural rights. The Limburg Principles that is further strengthened by the Maastricht guidelines clarified and set possible substantive standards that can be used to measure the realization of economic, social and cultural rights. ${ }^{21}$ The obligation of conduct and result highlighted the immediate action in a specific manner that has to be taken by State party and the measures taken is assessed by the outcome based approach by the
Committee on Economic, Social and Cultural Rights (Comm ESCR). The Comm ESCR also stated in the General Comment number 3 concerning the Nature of States Parties' Obligations that "to take steps" concept in Article 2 (1) is an immediate obligation and certain result has to be attained by the State Parties. 22

The idea of universal health care is heavily relied on the idea of commutative spirit that every individual cooperates together to realize a common goal. ${ }^{23}$ Universal health care is a means of pooling the public funds from public health care premium and government subsidies, then the funds is fairly distributed to individual who need it the most. The fundamental logic behind the cross-subsidy within universal health care is the healthy and wealthy subsidizes the unhealthy and poor. Universal health care aims to prevent financial hardship of an individual due to the existence of user fees. User fees are charged when an individual uses health facilities, goods and services. User fees are the main barrier to the fullest enjoyment of the right to health because not every person has equal financial capability to afford quality health goods, facilities and services. Within universal health care, health care financing is carried by all members of the society, thus, with cooperation and communal spirit, user fees can be reduced or even eliminated. Universal health care is also a means to reach the Sustainable Development Goals (SDGs) because the goal of SDGs in health

16 Siri Gloppen, "Litigation as A Strategy to Hold Government Accountable for Implementing the Right to Health", Health and Human Rights Journal, Vol. 10, Issue 2, 2008, pp. 21-36.

17 Ellie Palmer, 2007, Human Rights in Perspective: Judicial Review, Socio-Economic Rights and the Human Rights Act, Hart Publishing, Oxford, p. 14

8 Ibid.

19 Ibid.

20 Christian Tomuschat, 2008, Human Rights: Between Idealism and Realism, Second Edition, Oxford University Press, New York, p. 37; Matthew Craven, 1998, The International Covenant on Economic, Social and Cultural Rights, A Perspective on Its Development, Oxford University Pres, New York, pp. 8-9; Roland Burke, "Some Rights Are More Equal Than Others: The Third World and the Transformation of Economic, Social and Cultural Rights", Humanity: An International Journal of Human Rights, Humanitarian and Development, Vol. 3 , Issue 3, 2012, pp. 427-448.

21 International Commission of Jurists, "Limburg Principles on the Implementation of the International Covenant on Economic, Social and Cultural Rights, UN Doc. E/CN.4/1987/17”, Human Rights Quarterly, Vol. 9, 1987, pp. 122-135; International Commission of Jurists, "Maastricht Guidelines on Violation of Economic, Social and Cultural Rights", Human Rights Quarterly, Vol. 20, Issue 3, 1998 , pp. 695-697.

22 General Comment from the Committee has no binding nature, however, it has authoritative power over the State Parties because when a State ratified the Convention and Protocol, it accepted the authority of the Committee to interpret the words of the Covenant. The Comm ESCR, General Comment number 3, The Nature Of States Parties' Obligations, Fifth Session, 1990, U. N. Doc. E/1991/21, Annex III at 86, 1991, reprinted in Compilation of General Comments and General Recommendations adopted by Human Rights Treaty Bodies, U. N. Doc. HRI/ GEN/1/Rev.6 at 14, 2003, para. 2.

23 Edward Lee, "Universal Access to Health Care", Harvard Law Review, Vol. 108, 1995, pp. 1323-1340. 
is the assurance of healthy lives and promote wellbeing for all, those are the objective of universal health care. ${ }^{24}$

Indonesia ratified the International Covenant on Economic, Social and Cultural Rights in 2006 through the Law number 11 of $2005 .{ }^{25}$ Indonesia is legally bound by the State party human rights obligations under the ICESCR. In the synchronisation process of transforming international law into the national law, Indonesia has already had the constitutional platform for the right to health in the Article $28 \mathrm{H}$ and 34 of the Indonesian Constitution. ${ }^{26}$ The spirit of the Constitution is chrystalized in Pancasila as the ideational platform of the State, within the fifth principle of Pancasila, the right to health is guaranteed. Several laws have been promulgamated to support the establishment of universal health care, i) in the Law number 39 of 1999 concerning human rights protected the right to the highest attainable of health for every individual in Indonesia, ii) in the Law number 36 of 2009 concerning health, the Law guaranteed that every individual has the equal right to obtain access for health resources and quality health service, iii) in the Law number 40 of 2004 concerning National Social Security System, the Law mandated that social insurance is the right of the citizen and it has to be managed by a National Social Security Agency (BPJS), and iv) in the Law number 24 of 2011 concerning National Social Security Agency, the Law established the National Social Security Agency to manage the social insurance. Social insurance itself is divided into the National Health Insurance and National Employment Insurance. Article 22 of the National Social Security System Law guarantees that the benefit of universal health care takes form in the health service for individuals that includes promotive, preventive, curative and rehabilitative services. ${ }^{27}$

Before the establishment of the National Social Security Agency, Indonesia has a fragmented health insurance program through Jaminan Kesehatan Masyarakat (Jamkesmas or the National Health Insurance program) and Jaminan Kesehatan Daerah (Jamkesda or the Regional Health Insurance program). Within the National and Regional Health Insurance program, there are thematic health insurance programs such as the maternal delivery health insurance that is designed to ensure the health of pregnant mothers since pre-natal to postnatal. This fragmentation was problematic due to the complexity in health financing and quality assurance.

\section{International, Regional and National Legal Frameworks on Anti-corruption}

Corruption has been recognized as one of the oldest crime in the society. ${ }^{28}$ No civilization ever left untouched by the crime of corruption. ${ }^{29}$ In Indonesia, corruption is chronic, vicious and systemic, there are abundant cases of corruption that have been brought to the Court. ${ }^{30}$ Indonesia placed $88^{\text {th }}$ in the 2015 Corruption Perception Index by the Transparency International. ${ }^{31}$ Corruption itself is defined as the abuse of power for private

\footnotetext{
United Nations, "Sustainable Development Goals", https://sustainabledevelopment.un.org/topics/sustainabledevelopmentgoals accessed 26 January 2016

25 United Nations, “Treaty Series, https://treaties.un.org/pages/ViewDetails.aspx?src $=I N D \& m t d s g \_n o=I V-4 \&$ chapter $=4 \& l a n g=e n$, accessed 26 January 2016

26 Constitution of Republik Indonesia Year 1945.

27 Article 22 Law Number 40 Year 2004 concerning the National Social Security System (State Gazette of The Republic of Indonesia Year 2004 Number 150, Supplement to State Gazette of The Republic of Indonesia Number 4456).

28 Balakhrisnan Rajagopal, "Corruption, Legitimacy and Human Rights: the Dialectic Relationship", Connecticut Journal of International Law, Vol. 14, 1999, pp. 495-507.

29 Koffi Annan, Foreword for the United Nations Convention Against Corruption, General Assembly Resolution 58/4 of 31 October 2003; Morag Goodwin and Kate Rose Sender, December 2009, The Human Right to be Free of Corruption: A Dangerous Addition to the Development Discourse, Working Paper, Faculty of Law, Maastricht, pp. 1-20.

30 Nadisyah Hosen, "The Habibie Government and the Law on Eradication of Corruption in Indonesia", European Journal of Law Reform, Vol. V, Issue 1/2, 2003, pp. 293-321.

31 Transparency International, Corruption Perception Index.
} 
gain by the World Bank. ${ }^{32}$ Corruption has myriad forms, it is vary from embezzlement to bribery. ${ }^{33}$ Corruption has been seen as a serious crime and great impediment to development, ${ }^{34}$ thus in recent decades, international, regional and national legal continuum have been created in order to combat corruption.

On international level, there is the United Nations Convention Against Corruption (UNCAC) as the main international treaty to combat corruption. ${ }^{35}$ Indonesia ratified the UNCAC in 2006 through the Law number 7 of $2003 .{ }^{36}$ International legal framework is supported by regional legal framework against corruption, the existence of both formed a legal continuum in the fight against corruption. Regional legal instruments against corruption are Inter-American Convention Against Corruption $^{37}$, Council of Europe Criminal Law Convention on Corruption ${ }^{38}$, Additional Protocol of the Criminal Law Convention on Corruption ${ }^{39}$, Council of Europe Civil Law Convention on Corruption $^{40}$, European Union Convention on the Protection of the European Communities
Financial Interest ${ }^{41}$, First and Second Protocol of the Convention on the Protection of the European Communities Financial Interest ${ }^{42}$, Convention on the Fight Against Corruption Involving Officials of the European Communities or Officials of the EU Member States, ${ }^{43}$ Southern African Development Community Protocol Against Corruption, Economic Community of the West African States Protocol on the Fight Against Corruption, African Union Convention on Preventing and Combating Corruption. In Asia, there is no regional legal instrument with regard to anti-coruption, however, there is the Asian Development Bank Framework Policy on Anti-corruption and Integrity created by the Asian Development Bank. ${ }^{44}$ The existence of regional legal instruments strengthens the understanding that corruption is positioned as the threat of every State in the world. Each region has its own typology of corruption and measures to combat corruption. However, the civitas maxima gentium spirit that longs for clean government remains the same, corruption is everyone's enemy regardless of where an individual lives.

32 World Bank, 2005, Helping Countries Combat Corruption, The Role of the World Bank, 1995-2005, World Bank, Washington D. C, p. 77. This definition is also endorsed by the Transparency International, Transparency International, http://www.transparency.org/cpi2015, accessed 26 January 2016.

33 Daniel Treismann, "The Causes of Corruption: A Cross National Study", Journal of Public Economics, Vol. 76, 2000, pp. 399-457; Raaj Shah, "Corruption Across Countries and Regions: Some Consequences of Local Osmosis", Journal of Economic Dynamics and Control, Vol. 31, 2007, pp. 2573-2598.

34 Selcuk Akcay, "Corruption and Human Development", Cato Journal, Vol. 26, Issue 1, 2006, pp. 29-48; Joshua V. Barr, et al., "A Legal Perspective on the Use of Models in the Fight Against Corruption", South Carolina Journal of International Law and Business, Vol. 8, Issue 2, 2012, pp. 267-296; Augustine Ruzindana, "The Importance of Leadership in Fighting Corruption in Uganda”, in Kimberly Ann Elliott, 1997, Corruption and Global Economy, Institute for International Economics, Washington D. C, pp. 136-138; Roger P. Alford, “A Broken Window Theory of International Corruption", Ohio State Law Journal, Vol. 73, Issue 5, 2012, pp. 1253-1282.

35 United Nations, United Nations Convention Against Corruption, 2349 UNTS 41, Doc. A/58/422, 2003.

36 United Nations, United Nations Treaty Series, "Indonesia ratification of UNCAC", https://treaties.un.org/pages/ViewDetails. asp $?$ src $=I N D \& m t d s g \_n o=X V I I I-14 \&$ chapter $=18 \& l a n g=e n$, accessed 26 January 2016.

37 Inter-American Convention against Corruption 29 March 1996; C. A. Manfroni, 2003, The Inter-American Convention against Corruption, A Commentary, Lexington Books, Maryland, p. 1.

38 Council of Europe, Criminal Law Convention on Corruption, CETS No: 173, 2216 UNTS 225, 27 January 1999.

39 Additional Protocol to the Criminal Law Convention on Corruption, CETS No: 191, 2466 UNTS 168, 15 May 2003.

40 Council of Europe, Civil Law Convention on Corruption, CETS No: 174, 2246 UNTS 3, 4 November 1999.

41 European Union, Convention Drawn Up on the Basis of Article K of the Treaty of the European Union on the Protection of the European Communities' Financial Interests, ETS 2007, No. 166, 26 July 1995.

42 European Union, Protocol I to the Convention on the Protection of the European Communities' Financial Interests, ETS 2007, No. 169 (27 September 1996) and European Union, Protocol II to the Convention on the Protection of the European Communities' Financial Interests, ETS 2010, No. 8, 19 June 1997.

43 European Union, Convention on the Fight against Corruption involving Officials of the European Communities or Officials of the Member States of the European Union, Official Journal C 195/1 26 May 1997.

44 ADB and OECD Anti-corruption Initiative for Asia and the Pacific, Combating Corruption in the New Millenium, Tokyo, 30 November 2001. The Initiative established three pillars on anti-corruption, i) developing effective and transparent system for public service, ii) strengthening anti-bribery actions and promoting integrity in business operatons and supporting active public involvement; M. Sornarajah, "South East Asia and International Law", Singapore Journal of International and Comparative Law, Vol. 2, 1997, pp. 637-644. 


\section{Health Sector Corruption as the Arche- nemy of Universal Health Care in Indo- nesia}

The main purpose of the establishment of universal health care is to realize the right to health by providing accessible and affordable quality health care for all. In the General Comment of the Comm ESCR, accessible and affordable aspects of health care have to be supplemented also with availability and quality health care and it should fulfilthe Availibility, Accessibility, Acceptance and Quality standard (AAAQ). ${ }^{45}$ Specifically, Article 12. 2 (d) of the International Covenant on Economic, Social and Cultural Rights affirms that every individual has the right to health facilities, goods and services. ${ }^{46}$ Universal health care is a means to fulfill the core human rights obligation of the State party because universal health care guarantees assurance of availability and access to quality health facilities, goods and services on a non-discriminatory basis, especially for vulnerable or marginalized groups. ${ }^{47}$

Financing for universal health care is a crucial element in universal health care because it covers the costs of health care and directly counters the existence of user fees that is perceived to be the barrier in the realization of the right to health. Financing for universal health care must be based on the principle of equity. ${ }^{48}$ The principle of equity means that every citizen has the same equal right to universal health care, every citizen has to be covered by universal health care, however, the distribution of care should be based the medical need, inter alia, the prioritization should be given to vulnerable and marginalized groups ${ }^{49}$ User fees are the barrier to attain the highest standard of health. Based on the idealistic objective of the right to health, an individual's financial situation shall not impede his or her right to attain the highest standard of health. The existence of user fees can lead into two disaster narratives, i) an individual cannot afford the fees, ipso facto, he or she cannot obtain health goods, facilities and services or ii) due to the fees, the health institutions lower the quality or quantity of health care facilities, goods and services to fit the shortage of financial situation. Without universal health coverage, people have high risk of financial catastrophe when they are ill. The main purpose of universal health care, financially, is to reduce or eventually eliminate the user fees from the patients. ${ }^{50}$

In Indonesia, universal health care is a twotiered program universal health care. There is compulsory membership obligation for every citizen and foreigner whom resides in Indonesia more than six months. Indonesia provides alternatives to offer its citizens with option for private health care. Therefore, one person can have dual membership of public and private health insurance if he or she can afford the premium. Indonesia established the National Social Security Agency to manage the pool of fund from the premium of insurers and the subsidy for poor and near poor citizen from the Government's fund. ${ }^{51}$ When $J K N$ and the National Social Security Agency were introduced in 2014, the Corruption Eradication Commission has stated that the fund for $J K N$ is prone to be corrupted due to the large funds of 40 trillion rupiah every year and the single authority possessed by the National Social Security Agency. ${ }^{52}$ Power must be checked

\footnotetext{
45 The General comment of the Committee on Economic, Social and Cultural Rights, paragraph 12.

4 General Comment number 14 of the Right to Health, paragraph 17. The Committee stressed that, "A further important aspect is the improvement and furtherance of participation of the population in the provision of preventive and curative health services, such as the organization of the health sector, the insurance system and, in particular, participation in political decisions relating to the right to health taken at both the community and national levels".

47 General Comment number 14 of the Right to Health, paragraph 43.

4 Thematic Group on Health for All, 24 February 2015, Financing Universal Health Coverage in the Post-2015 Agenda, Issue Brief, pp. 1-11 Ibid.

WHO, 2013, Research for Universal Health Coverage, The World Health Report, World Health Organization, Geneva, pp. 6-7.

Ibid.

Jakarta Post, "KPK Monitor BPJS Funds", http://www.thejakartapost.com $/$ news $/ 2014 / 02 / 11 / k p k$-monitor-bpjs-funds.html, accessed 26 January 2016.
} 
by another power to keep the accountability intact. Without the check and balance, power will corrupt as what Lord Acton has theorized that power tends to corrupt and absolute power corrupt absolutely. ${ }^{53}$ It is the basic theory of Montesquiue in his theory of power separation and the separation of power is not yet established within the National Social Security Agency. ${ }^{54}$ On empirical level, Indonesia is facing a great challenge in the establishment of universal health care because based on the Concluding Observation of the Comm ESCR, Indonesia should have expanded the capacity and the quality of health care especially in undeserved regions. ${ }^{55}$ The Comm ESCR noted that the health care system in Indonesia is not yet able to meet the demand of health goods, facilities and services following the introduction of the Universal Health Care. ${ }^{56}$

There is ample evidence of legal cases concerning health sector corruption. In this article, three legal cases are used to exemplify the situation of health sector corruption in Indonesia. The first legal case is the case of Jamkesmas fund embezzlement within the health centres located in Purabaya, West Java. Jamkesmas was the Government health care program before the establishment of $J K N$ in 2014. The aim of the program was to give access to quality health care for the poor and near-poor people. The convict is H. Ihsan Sanusi, he was the head of health centres in Purabaya and three sub-health centres in Cimerang, Cikukang and Citameang villages in West Java.$^{57}$ The Ministry of Health was annually published a Guidance Manual for Jamkesmas Spending to ensure that every government's employee understood their role in Jamkesmas spending. The Guidance obliged the health centre to appoint a treasurer for the fund in order to create a check and balance mechanism between the head of health centre and the treasurer.

After the appointment of the treasurer, the head of the health centre together with the treasurer shall formulate a plan of action for Jamkesmas fund, then the plan has to be sent to the Ministry of Health. In this case, after the fund is obtained by the head of health centre, subsequently, the treasurer was exempted from any activity with regard to the fund. Due to that exemption, any activity went beyond control mechanism of the treasurer, the head of health centres appointed an honorary treasurer and demanded him to follow his orders, inter alia, making financial reports based only on the subjective narrative from the head of health centres and he was ordered to falsify signatures for administrative details in every spending. ${ }^{58}$ There was an unexplainable margin of loss amounted to Rp. 135.758.760,00 in the financial responsibility reports of 2008 and 2009. ${ }^{59}$ Four elements of rationae personae, the mens rea to gain private benefit, the actus reus to abuse the power bestowed upon him and the impact that is the loss of State fund were proven in the Court. ${ }^{60} \mathrm{He}$ was guilty for the act of embezzlement that is the act of diverting the fund with purpose of personal enrichment. ${ }^{61}$ The Court concluded that the head of health centres was proven beyond reasonable doubt that he had corrupted Jamkesmas fund by the criminal act of embezzlement by the State official. ${ }^{62}$ The Court based its decision on the Art. 3 of the Law number 31 of 1999 in conjunction with the Art. 8 of the Law number 20 of 2001.63

The second legal case is the case of

\footnotetext{
Brian Martin, 1998, Information Liberation, Challenging the Corruptions of Information Power, Freedom Press, London, p. 1.

54 Montesquieu, "The Spirit of Laws", edited by Anne M. Cohler, et al., 1989, Cambridge Texts in the History of Political Thoughts, Montesquieu, the Spirit of Laws, Cambridge University Press, Cambridge, pp. 155 and 164.

The Comm ESCR, Concluding Observations on Initial Report of Indonesia, E/C.12/IDN/CO/1 19 June 2014, para. $2 .$, p. 3.

Ibid.

Court Decision Cibadak No. 607/Pid.B/2010/PN.Cbd, 16 February 2011.

Ibid.

Ibid.

Ibid.

Art. 8 of The Law Number 20 of 2001 concerning The Change of The Law Number 30 Year 1999 concerning Corruption Eradication ( State Gazette of The Republic of Indonesia Year 2009 Number 143, Supplement to State Gazette of The Republic of Indonesia Number 5062).

Court Decision Cibadak No. 607/Pid.B/2010/PN.Cbd, 16 February 2011.

63 Ibid.
} 
Jamkesmas fund embezzlement in Aceh Tamiang by the treasurer of Jamkesmas fund, her name is Syarifah Umi Kalsum. Her responsibility as the treasurer were to take Jamkesmas fund from the designated bank account, to pay medical services fees and to make a financial report of Jamkesmas fund. ${ }^{64}$ The purpose of Jamkesmas fund is to financially support regional hospitals in order to give access to poor and near poor people..$^{65}$ The fund can only be reimbursed after the hospital finished giving medical services to the people. ${ }^{66}$ The mechanism for reimbursement is the hospital offered claim that consists of patient's data from every room. The data are the evidence that the medical service has been given to the patients to the internal verificator of regional hospital Aceh Tamiang. After that, the internal verificator verify and recapitulate the data then send it to the independent verificator, before that, the data has to be duly signed by the director of the hospital and the independent verificator in tandem. Subsequently the whole file is sent to the Central Manager of Jamkesmas in the Department of Health, a sub-organ under the authority of the Ministry of Health. The Department of Health will send the file to the independent verificator to verificate it once more before giving assessment. ${ }^{67}$

The Court found that the Jamkesmas fund amounted to Rp. 181.831.050,00 has not been paid by the treasurer. ${ }^{68}$ She confessed that the director of hospital ordered her to pay for the goods and services that should not be paid by the Jamkesmas fund. In order to fulfill the administrative requirements of reimbursement, the treasurer created false documents in a form of patient's list in 2009 and falsified the patients's signatures to complete the documents. ${ }^{69}$ The result was, even though, the treasurer did not pay the remaining medical fees to the righteous hands but in order to fulfill the financial administrative requirements, acting as the treasurer of Jamkesmas, she falsified the signatures so the payment for Rp. 181.831.050,00 could be made. ${ }^{70}$ The Court concluded that there was a loss of State's fund that legally classified as a crime of corruption. ${ }^{71}$

The third legal case is the case of embezzlement of maternal health fund in 2014. Indonesia had the maternal health care program that covers the service of maternal health since pre-natal to post-natal. The program was established under the umbrella of the Ministry of Health. ${ }^{72}$ The objective of the program is to give free pre-natal to post-natal services for the women. The fund is used by the Government to pay the fee of the midwives thus, ipso facto, give free service to the patients. The fund is distributed by the Central Government through the Ministry of Health to the hospitals and health centres. The administrative requirements for the payment of the midwives are the copy of patient's national identification card or the domicile card, the copy of patient's maternal health check up book and the obstetric ultrasonography. ${ }^{73}$ The convict was a midwife whom falsified the data of the patients in order to add the amount of patients into the report. The Court concluded that the convict had abused her authority by making false data for the payment of the delivery service and the abuse of power that she made was legally classified as a criminal act of corruption. ${ }^{74}$ The Court established the legal argument that there was a loss of State's fund caused by fraud that was conducted by the convict. ${ }^{75}$

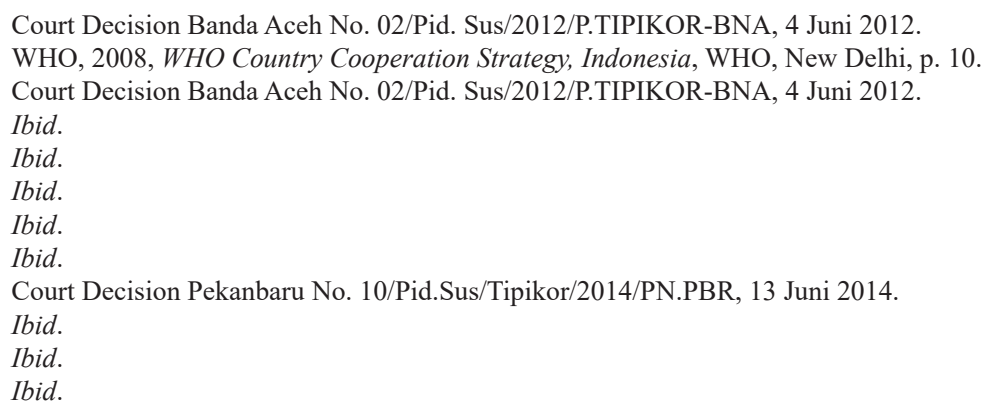


In order to effectively govern the society, a government has to embody the principle of good governance such as transparency, nondiscrimination and accountability. These principles are important to ensure the realization of human rights. Corruption, in juxtaposition, is contrary to every principle of good governance. ${ }^{76}$ Corruption has an adverse nature to every principle of good governance. The secretive nature of corruption clashed perfectly with the transparency principle of good governance. Corruptors, deontologically, abuse the power bestowed upon them for their own private benefits. It is very detrimental to the system because a corruptor caused damage and malfunction towards the whole system. Universal health care system demands that every organ is functioning properly to ensure the success of the program. The formulation of the bureaucratic structure in universal health care system has the purpose that every individual carry on his or her mandate in accordance with the rules.

In contextualization with the legal cases, as a public employee who has given a mandate by the Government to manage Jamkesmas, consequently, an individual has to manage, distribute and be accountable with bona fide for the use of fund. In the legal cases, the convicts abused their mandate for their own private benefits. They falsified the data in order to embezzle the fund. As the result, the fund that should have been used to provide availability and accessibility to quality health facilities, services and goods could not be enjoyed by the individuals as their realization of the right to health. The corruptors misallocated, then embezzled the fund while the fund should have been used to pay the health services, reimburse the fee of midwives and establish access to health facilities, goods and services for poor and near poor individuals.

Universal health care as a means to ensure the right to health is guided by the AAAQ standard.
Corruption is an archenemy to universal health care because it violates the standard. When there is corruption, the fund that should be used to ensure the availability, accessibility, acceptance and quality health care is reduced by the corruptors. In those three legal cases, more than fifty percent of the fund is embezzled by the corruptors and left the constituents with a decreased chance for optimum quality universal health care. The fund could have been used to cover more people and improve the quality of health care goods, facilities and services. It has a direct detrimental impact towards the realization of the right to health. Even though, in an imaginative situation that there was absolutely no health sector corruption, Indonesia has already facing shortage in providing access to quality universal health care because based on the Comm ESCR recommendation, Indonesia has to improve it's health care coverage by raising the public spending on universal health care and manage the fund with due diligence. ${ }^{77}$

$J K N$ as the luminal point for realization of the right to health could have been effectively worked if there was no health sector corruption. The State party of international human rights instruments has tripartite human rights obligations to respect, protect and fulfil human rights. In this research, corruption in health sector in the form of embezzlement by the State official does hamper the ability of the State party to carry on its tripartite human rights obligations. This phenomenon is an evidence that there is an urgent need to incorporate human rights legal continuum into anti-corruption strategy because the realization of right to health as described by the existence of $J K N$ as universal health care is endangered because of corruption in health sector. Therefore, in order to effectively realize human rights, specifically the right to health, the State party of international human rights instruments should prioritize on anti-corruption strategy

\footnotetext{
76 C. Raj Kumar, "Corruption and Human Rights: Promoting Transparency in Governance and the Fundamental Rights of Corruption-Free Service in India”, Columbia Journal of Asian Law, Vol. 17, Issue 1, 2003-2004, pp. 31-72.

77 Court Decision Pekanbaru No.10/Pid.Sus/Tipikor/2014/PN.PBR, 13 Juni 2014.
} 


\section{Conclusion}

Indonesia has taken the correct step in the realization of the right to health through the establishment of universal health care. Based on the legal cases, health sector corruption endangers the existence of an ideal universal health care, ipso facto, endangers the realization of the right to health in Indonesia. Health sector corruption directly reduced the fund that should have been used to finance universal health care and caused a direct detrimental impact towards the realization of the right to health. The elimination of health sector corruption by the means of taking human rights consideration into anti- corruption strategy have to be taken into primary consideration for the success of universal health care. A clean government free from corruption is a condition sine qua non for the availability and accessibility of quality universal health care.

\section{REFERENCES}

\section{A. Books}

Cohler, Anne M., et al., 1989, Cambridge Texts in the History of Political Thoughts, Montesquieu, the Spirit of Laws, Cambridge University Press, Cambridge.

Elliott, Kimberly Ann, 1997, Corruption and Global Economy, Institute for International Economics, Washington D. C.

Manfroni, A., 2003, The Inter-American Convention against Corruption, A Commentary, Lexington Books, Maryland.

Martin, Brian, 1998, Information Liberation, Challenging the Corruptions of Information Power, Freedom Press, London.

Palmer, Ellie, 2007, Human Rights in Perspective: Judicial Review, Socio-Economic Rights and the Human Rights Act, Hart Publishing, Oxford.

Tomuschat, Christian, 2008, Human Rights: Between Idealism and Realism, Second Edition, Oxford University Press, New York. WHO, 2008, WHO Country Cooperation Strategy, Indonesia, WHO, New Delhi.

WHO, 2013, Research for Universal Health Coverage, The World Health Report, World Health Organization, Geneva.

World Bank, 2005, Helping Countries Combat Corruption, The Role of the World Bank, 1995-2005, World Bank, Washington D. C.

\section{B. Journal Articles}

Akcay, Selcuk, "Corruption and Human Development", Cato Journal, Vol. 26, Issue 1, 2006.

Alford, Roger P., "A Broken Window Theory of International Corruption", Ohio State Law Journal, Vol. 73, Issue 5, 2012.

Barr, Joshua V., et al., "A Legal Perspective on the Use of Models in the Fight Against Corruption", South Carolina Journal of International Law and Business, Vol. 8, Issue 2, 2012.

Burke, Roland, "Some Rights Are More Equal Than Others: The Third World and the Transformation of Economic, Social and Cultural Rights", Humanity: An International Journal of Human Rights, Humanitarian and Development, Vol. 3, Issue 3, 2012.

Braveman, Paula, "Social Conditions, Health Equity and Human Rights", Health and Human Rights Journal, Vol. 12, Issue 2, 2010.

Butt, Simon , "Indonesia's Anti-Corruption Drive and the Constitutional Court", Journal of Comparative Law, Vol. 4, Issue 2, 2010.

Cassing, James, "Indonesia in Transition: Will Economic Prosperity Accompany Democracy", Brown Journal of World Affairs, Vol. IX, Issue I, Spring 2002

Doebbler, Curtin Francis, "The Right to Health of 
Children and the World Bank", Health and Human Rights Journal, Vol. 5, Issue 2, 2001.

Duger, Angela, "Focusing on Prevention: The Social and Economic Rights of Children Vulnerable to Sex Trafficking", Health and Human Rights Law Journal, Vol. 17, Issue 1, 2015.

Gloppen, Siri, "Litigation as A Strategy to Hold Government Accountable for Implementing the Right to Health", Health and Human Rights Journal, Vol. 10, Issue 2, 2008.

Hosen, Nadisyah, "The Habibie Government and the Law on Eradication of Corruption in Indonesia", European Journal of Law Reform, Vol. V, Issue 1/2, 2003.

International Commission of Jurists, "Limburg Principles on the Implementation of the International Covenant on Economic, Social and Cultural Rights, UN Doc. E/ CN.4/1987/17", Human Rights Quarterly, Vol. 9, 1987.

International Commission of Jurists, "Maastricht Guidelines on Violation of Economic, Social and Cultural Rights", Human Rights Quarterly, Vol. 20, Issue 3, 1998.

Jacobs, Leslie Gielow and Wagner, Benjamin B., "Limits to the Independent Anti-Corruption Commission Model of Corruption Reform: Lessons from Indonesia", Global Business and Development Law Journal, Vol. 20, 2007.

Kumar, Raj, "Human Rights Approaches to Corruption Control Mechanisms-Enhancing the Hong Kong Experience of Corruption Prevention Strategies", San Diego International Law Journal, Vol. 5, 2004. , "Corruption and Human Rights: Promoting Transparency in Governance and the Fundamental Rights of Corruption-Free Service in India", Columbia Journal of Asian Law, Vol. 17, Issue 1, 2003-2004.

Lee, Edward, "Universal Access to Health Care", Harvard Law Review, Vol. 108, 1995.

Levinson, Jared, “Indonesian's Odyssey: A Nation's
Long, Perilous Journey to the Rule of Law and Democracy", Arizona Journal of International and Comparative Law, Vol. 18, Issue 1, 2001.

Mayhew, Sussanah, et al., "Balancing Protection and Pragmatism: A Framework for NGO Accountability in Rights-Based Approaches", Health and Human Rights Journal, Vol. 2, Issue 2, 2006.

O’Neill, Kathryn, “Monitoring Service Delivery for Universal Health Coverage: the Service Availibility and Readiness Assessment", Bull World Health Organ, Vol. 91, 2013.

Rajagopal, Balakhrisnan, "Corruption, Legitimacy and Human Rights: the Dialectic Relationship", Connecticut Journal of International Law, Vol. 14, 1999, pp. 495507.

Shah, Raaj, "Corruption Across Countries and Regions: Some Consequences of Local Osmosis", Journal of Economic Dynamics and Control, Vol. 31, 2007.

Sornarajah, M., "South East Asia and International Law", Singapore Journal of International and Comparative Law, Vol. 2, 1997.

Treismann, Daniel, "The Causes of Corruption: A Cross National Study", Journal of Public Economics, Vol. 76, 2000.

Toebes, Brigit, "The Right to Health and the Privatization of National Health Systems: A Case Study of the Netherlands", Health and Human Rights Journal, Vol. 9, Issue 1, 2006.

Tyler, Tobin, "Small Places Close to Home": Toward A Health and Human Rights Strategy for the U. S.", Health and Human Rights Journal, Vol. 15, Issue 2, 2013.

Yamin, Alicia Ely, "Shades of Dignity: Exploring the Demands of Equality in Applying Human Rights Frameworks to Health", Health and Human Rights Journal, Vol. 11, Issue 2, 2009.

Vian, Taryn, et al., "Barriers to Universal Health Coverage in Republic Moldova: A Policy Analysis of Formal and Informal Out of 
Pocket Payments", BMC Health Services Research, Vol. 15, 2015.

Jacobs, Leslie Gielow and Wagner, Benjamin B.,

"Limits to the Independent Anti-Corruption Commission Model of Corruption Reform: Lessons from Indonesia", Global Business and Development Law Journal, Vol. 20, 2007

King, Dwight, "Corruption in Indonesia: A Curable Cancer?", Journal of International Affairs, Vol. 53, Issue 2, 2002

Jacobs, Leslie Gielow and Wagner, Benjamin B., "Limits to the Independent Anti-Corruption Commission Model of Corruption Reform: Lessons from Indonesia", Global Business and Development Law Journal, Vol. 20, 2007.

\section{Research Report}

Goodwin, Morag and Sender, Kate Rose, The Human Right to be Free of Corruption: A Dangerous Addition to the Development Discourse, Working Paper, Maastricht.

World Bank, 2003, Combating Corruption in Indonesia, Enhancing Accountability for Development, Report, East Asia Poverty Reduction And Management Unit, Washington DC.

\section{Article Internet}

Haydock, Ian, "Asian Beat:Political Breathrough Edges Indonesia Closer to Universal Health Care", http://www.pharma-share.com/ asia-beat-political-breakthrough-edgesindonesia-closer-universal-care, accessed 1 January 2016.

International, Transparency International, http:// www.transparency.org/cpi2015, accessed 26 January 2016.

Jakarta Post, "Govt Provide Universal Health Coverage", http://www.thejakartapost.com/ news/2012/10/13/govt-provide-universalhealth-coverage-all.html, accessed 1 January 2016.

Jakarta Post, "KPK Monitor BPJS Funds", http:// www.thejakartapost.com/news/2014/02/11/ kpk-monitor-bpjs-funds.html, accessed 26 January 2016.

Transparency International, "Corruption Perception Index 2015”, www.transparency.org, accessed 1 January 2016.

United Nations, United Nations Treaty Series, Indonesia ratification of UNCAC, https:// treaties.un.org/pages/ViewDetails. aspx?src $=I N D \& m t d s g \_n o=X V I I I-$ $14 \&$ chapter $=18 \&$ lang $=$ en, accessed 26 January 2016.

United Nations, "Treaty Series, https:// treaties.un.org/pages/ViewDetails. asp $x$ ? src $=I N D \& m t d s g_{-} n o=I V-$ $4 \&$ chapter $=4 \&$ lang $=e n, \quad$ accessed 26 January 2016.

United Nations, "Sustainable Development Goals", https://sustainabledevelopment. un.org/topics/sustainabledevelopmentgoals accessed 26 January 2016.

\section{E. Regulations}

Law Number 20 of 2001 concerning The Change of The Law Number 30 Year 1999 concerning Corruption Eradication ( State Gazette of The Republic of Indonesia Year 2009 Number 143, Supplement to State Gazette of The Republic of Indonesia Number 5062).

Law Number 40 Year 2004 concerning the National Social Security System (State Gazette of The Republic of Indonesia Year 2004 Number 150, Supplement to State Gazette of The Republic of Indonesia Number 4456).

Law Number 11 of 2005 concerning the Ratification of the International Covenant on Economic, Social and Cultural Rights (State Gazette of The Republic of Indonesia Year 2005 Number 118, Supplement to State Gazette of The Republic of Indonesia Number 4557).

\section{F. Others}

Additional Protocol to the Criminal Law Convention on Corruption, CETS No: 191, 2466 UNTS 
168, 15 May 2003.

Annan, Koffi, Foreword for the United Nations

Convention Against Corruption, General

Assembly Resolution 58/4 of 31 October 2003.

Court Decision Pekanbaru No.10/Pid.Sus/ Tipikor/2014/PN.PBR, 13 Juni 2014.

Court Decision Pekanbaru No. 10/Pid.Sus/ Tipikor/2014/PN.PBR, 13 Juni 2014.

Court Decision Banda Aceh No. 02/Pid. Sus/2012/P. TIPIKOR-BNA, 4 Juni 2012.

Court Decision Cibadak No. 607/Pid.B/2010/ PN.Cbd, 16 February 2011.

Council of Europe, Civil Law Convention on Corruption, CETS No: 174, 2246 UNTS 3, 4 November 1999.

European Union, Protocol I to the Convention on the Protection of the European Communities' Financial Interests, ETS 2007, No. 169 (27 September 1996) and European Union, Protocol II to the Convention on the Protection of the European Communities'
Financial Interests, ETS 2010, No. 8, 19 June 1997.

The Comm ESCR, Concluding Observations on Initial Report of Indonesia, E/C.12/IDN/ CO/1 19 June 2014.

Thematic Group on Health for All, 24 February 2015, Financing Universal Health Coverage in the Post-2015 Agenda, Issue Brief.

The General Comment number 14 of the Right to Health.

The General comment of the Committee on Economic, Social and Cultural Rights.

The Committee on Economic, Social and Cultural Rights (Comm ESCR) General Comment Comment number 14, paragraph 9.

United Nations, United Nations Convention Against Corruption, 2349 UNTS 41, Doc. A/58/422, 2003.

Universal Declaration of Human Rights, UN GA Resolution 217 (III), $3^{\text {rd }}$ Session, Supp. No. 13, UN Doc A/810, 1948 